\title{
Exploring Information Technology and Total Quality Management Implementation by Food and Drink Manufacturing Enterprises
}

\author{
Sofia Zioupou, Aristotle University of Thessaloniki, Thessaloniki, Greece \\ Basil Manos, Aristotle University of Thessaloniki, Thessaloniki, Greece \\ Zacharoula Andreopoulou, Aristotle University of Thessaloniki, Thessaloniki, Greece \\ Irini Tzimitra-Kalogianni, Aristotle University of Thessaloniki, Thessaloniki, Greece
}

\begin{abstract}
The purpose of this study was to examine the implementation of Total Quality Management (TQM) as a business strategy in the Greek food and drink industry, along with the examination of the Information Technology (IT) adoption in the field. A research project was carried out in the sector companies based in Greece, using the questionnaire method. Findings showed a strong relation between IT implementation and impact of IT on TQM. Company size also seemed to affect TQM implementation, and the majority of IT implementation constructs, while company performance was not significant in terms of net profit margin and value added per employee.
\end{abstract}

\section{KEYWORDS}

company performance, Food and drink sector, Information Technology, Total Quality Management

\section{INTRODUCTION}

According to Gabriel et al. (2000), the term Information Technology (IT) is used to describe a set of instruments, other than computers, machines and systems for collecting, storing, processing and communicating information. Furthermore, IT refers to anything related to computing technology, such as networking, hardware, software, the Internet, or the people that work with these technologies (Christensson, 2006). Since the 1980s, IT has been a facilitator of change in the business world, advancing processing speeds and the capacity to store and share information through seamless integration of an organization's processes and systems (Davenport, 1998), irrespective of time and distance (Chandiwana \& Pather, 2016). As stated by Lee (2005), IT is reshaping business performance and economic growth globally, by reducing the cost of coordination, communication, and information processing.

The modernization of enterprises (both manufacturing and service providers) through the use of IT, is a critical factor for their success, competitiveness and growth. As larger businesses are exploring the benefits offered through IT, the smaller ones are called to follow their steps, risking otherwise of not being competitive (European Commission, 2017). Moreover, an improvement of the quality management is expected via the application of IT (Khanam et al., 2014).

Porter and Millar (1985), recorded three ways in which IT influence competition, offering a comparative advantage (McFarlan, 1984) to companies that use them. More specifically, have led to 
changes in the structure and competition of industries, used to support the creation of new businesses and create competitive advantage for the companies using IT, so to outweigh their competition.

On the other hand, the concept of quality is hard to be defined, based on the literature. It is worth noting that even the quality gurus who have dealt with the theory in depth (Crosby, 1979; Deming, 1986; Garvin, 1984; Juran, 1988; Juran \& Gryna, 1993) have defined quality in their own specific way. As an example, researchers notice that the English Oxford Living Dictionary (English Oxford living Dictionaries, 2016) defines quality as "a degree or level of excellence", while the definition given by the American National Standards Institute (ANSI) and the American Society for Quality Control (ASQC) is "the totality of characteristics of a product or service that is capable of satisfying given needs". Garvin (1988) in his book "Managing Quality - The Strategic and Competitive Edge" highlights the peculiarity of the definition of quality, describing the concept as "an unusually slippery concept", which is easy to depict, but also extremely difficult to define. For Feigenbaum (1983) quality is defined as "being about value", while Crosby (1979) defines quality as "conformance to standards, specifications or requirements". On the other hand, Juran (1988) suggests that quality is "fitness for use", while Peters and Waterman (1982) claim "quality as excellence" and Parasuraman et al. (1985) suggest that "quality is concerned with meeting or exceeding customer expectations".

The available literature includes numerous studies regarding the adoption of TQM by Greek companies (Bouranta et al., 2017; Dervitsiotis, 1999; Fotopoulos \& Psomas, 2009; Gotzamani et al., 2006; Kampouridis et al., 2015; Psychogios \& Wilkinson, 2007; Tsiotras \& Gotzamani, 1996; Vranaki et al., 2015). In the present study, an attempt is made to approach the relationship between IT and TQM, particularly in food and drink companies based in Greece.

Quality is a very important factor in the food industry, as it deals with highly sensitive products. Maintaining quality standards and adhering to quality requirements are imperative for the companies of the sector. In order to maintain customer satisfaction and loyalty and reduce the risk and cost of defective products, food companies pay particular attention to maintaining quality through TQM and IT. This is the main reason that this study focuses on the food industry.

This paper is constructed as follows. In section 2, literature review regarding the research area is presented. Section 2 reviews previous studies related to TQM and IT implementation and their impact to companies' organizational and quality performance. Section 3 describes the importance of the Greek food and drink sector, for country's economy, being dynamic, competitive and extroverted and a main driving force of manufacturing in the country. In the fourth section, the methodology followed, as well as the questionnaire used, are presented, followed by the findings of the analysis (section 5). Finally, section 6 summarizes the results and section 7 presents certain limitations and recommendations for further research.

\section{LITERATURE REVIEW}

Numerous researchers have dealt with TQM, trying to enlighten several issues that have emerged from its application in business administration. References are mentioned below. Douglas and Judge (2001) discovered a strong support on the relationship between the extension of TQM implementation and the competitive advantages achieved. Several studies explored the impact of TQM adoption to organizational and quality performance (Agus et al., 2007; Fuentes \& Montes, 2006; Talib et al., 2013), while others tried to identify the relationship between TQM practices and organizational culture, resulting in different subsets of TQM practices to be determined by different types of culture (Prajogo \& McDermott, 2005).

Using the confirmatory factor analysis approach, Isaac et al. (2004) identified critical success factors in TQM implementation in the software industry and suggested a framework for quality management. Sila (2007) developed a model combining the effects of seven TQM practices on four measures of organizational performance. The effects of theses performance measure on each other, by using survey method. studied Sajjad \& Amjad (2012) attempted to determine the various benefits 
deriving from the application of TQM practices for an organization, or the relationship between TQM and quality outcomes/benefits in the services sector of the telecom industry of Pakistan, while Siddiqui \& Rahman (2007) conducted a study to access the role of TQM and Information Systems (IS) in an effort to achieve organizational goals in Indian industry.

According to the European Commission (2017), the use of IT by companies in both manufacturing and services is a critical factor for success in innovation, competitiveness and growth. Tsakanikas et al. (2014) in their report about ICT Adoption and Digital Growth in Greece, mention that IT represents the key for innovation and growth of national economies worldwide, while adopting this form of innovation could be a basic policy priority for developed economies. IT penetration in businesses and especially in SMEs makes an effective contribution to the improvement and implementation of productivity, innovativeness and generally to the competitiveness of businesses. According to Tsakanikas et al. (2014), "new digital technologies and innovations evolve rapidly affecting many industries and value chains", while the use of IT can help businesses identify and take advantage of new opportunities and challenges.

Concerning research about both IT and TQM implementation, many attempts have been conducted to approach this research issue. It is noticeable that interest remains stable in this ever-evolving field. Some examples of research are presented below. Eng et al. (2003) investigated the level of practice on TQM elements, identifying critical factors perceived by the enterprises, focusing on the importance of TQM adoption to "meet upcoming challenges". Dewhurst et al. (2003) and Martinez-Lorente et al. (2004) investigated the interaction between TQM and IT in Spanish companies, analyzing the way in which TQM is influenced by IT, indicating that "the most intensive users of IT perceive a bigger impact on their TQM dimensions".

Companies' competitiveness could be improved by Quality Management and the role of IT in this equation is crucial, based on Ahmed et al. (1999), Demirbag et al. (2006), Perez-Arostegui et al. (2012), and Reed et al (2000). Ginige \& Samarasinghe (2008) presented an empirical study which examines the interrelationship between IT and TQM and the importance of these practices on organizational performance in terms of quality effectiveness. Perez-Arostegui et al. (2012) used structural equation modeling to analyze the complementarity between IT and Quality Management Practices (QMP) in Spanish firms, showing a positive and significant relationship between IT and QMP. Matta, et al. (1998) described a theoretical framework that analyzes the impact of a set of IT tools in the enterprise for successful implementation of QM practices. Moreover, Keramati \& Albadvi (2009) explored the effects of integration of IT and TQM on the performance of SMEs in the Swedish industry. Tiwari \& Chaudhri (2012) investigated the effect of IT on TQM, through a survey of industries based in India, while Ang et al. (2000) explored measures to assess the impact of IT to support TQM processes in the Malaysian public sector.

Parzinger \& Nath (2000) assessed the relationship between TQM implementation and certain measures of software quality. Abdi et al. (2013) analyzed the relevant knowledge of TQM theories and principles to facilitate improving IT product/services practices, while Sanchez-Rodriguez et al. (2011) provided an insight into IT and TQM theory and practices, on operational \& quality performance of the firm. The role of IT in implementing TQM was also investigated by Siam et al. (2012). Other researchers (Alqahtani et al., 2017; Bandyopadhaya, 2003; Gunasekaran et al., 2006;) suggested specific frameworks for implementing TQM and IT, like TISIT, TQMIS etc. Perez-Arostegui et al. (2015) examined the relationship between the efficient use of IT and Quality Management (QM), concluding that the effective use of IT in the enterprise has a direct and positive impact on QM implementation (measured by seven QM practices).

None of the above-mentioned studies focused on the food industry. Some of them included food companies in their sample, but not exclusively. This study aims to examine the current situation on the Greek-based food and drink companies. The main purpose of this study is to assess the effect of TQM and IT implementation on business performance, regarding companies in the food and drink sector in Greece, since there is not such a similar research in the field. Moreover, this study examines the impact that IT has on TQM implementation and the role of IT. 


\section{GREEK FOOD AND DRINK INDUSTRY}

Nowadays, the Greek food and drink industry maintains a fundamental role to the Greek manufacturing industry and to country's economy. The sector has consistently been one of the most important ones of the domestic economy. It is considered as a main driving force of manufacturing in the country, being dynamic, competitive and extroverted, with significant investment and business activity in Greece, the Balkans and across Europe. The food and drink industry has maintained its fundamental role over the years, even in the prolonged period of recession for Greek economy, having demonstrated that it has the prerequisites to remain key growth driver (FEIR, 2017).

The Greek food industry accounts for $25 \%$ of all Greek processing enterprises, ranking first among the manufacturing sector, while it is also the largest employer of domestic manufacturing, employing more than $28 \%$ of the total employees, compared to $9 \%$ in metal products and $6 \%$ in the clothing sector. Moreover, food and drink industry is among the first manufacturing sectors, as its production value reaches $20 \%$ and gross value added exceeds $26 \%$. The sector holds the second place in terms of turnover (FEIR, 2017).

A recent study of the Foundation for Economic \& Industrial Research (Tsakanikas et al., 2014) showed that ICT adoption in Greek SME's, increases, approximately 4-9\%, their probability to innovate, while ICT penetration in Greek SME's, facilitates significantly their internationalization, since it increases approximately $1.5-4 \%$, their likelihood to export.

\section{METHODOLOGY}

A structured questionnaire with closed-ended questions was used to collect the data. The instrument was originally suggested by Martinez-Lorente et al. (2004) and was adapted based on the current status, availability and use of IT in enterprises and the structure of the food sector in Greece. Changes made to the given questionnaire relate to the IT technologies used by food and drink companies, as IT service providers reported particularly regarding the food industry. The suggested questionnaire was then tested by specialists in quality and technology industry, in order to be applied thoroughly, not to leave ambiguous notions and to be understood by business quality managers.

The survey was conducted in a sample of 250 industrial enterprises of the food and beverage sector based in Greece, which were chosen based on two criteria. The first selection criterion for the companies was their average turnover recorded in the past three-year period, as turnover seems to be related to the adoption of IT and TQM, shown by previous studies. Moreover, each company of the selected sample had also to record profit in 2014. It's worth noting that only $48.3 \%$ of the total food companies were profitable both in 2013 and 2014, while 11.1\% recorded a profit in 2013 and loses in 2014, and 26.9\% were loss-making in 2013 and remained loss-making in 2014 (Korfiatis, 2017). Thus, 250 profitable companies in 2014 with the highest average turnover (2012-2014) were selected, from both food and beverage sector. Official balance sheets of the enterprises were requested, through the General Commercial Register, the websites of the companies and the local chambers.

The questionnaires were sent via email to the quality managers of each company. In addition, personal interviews were conducted in order to increase the number of questionnaires answered, reaching a total of 39 questionnaires in the end of the research. Five questionnaires were found to be invalid and were removed from the total, while the analysis proceeded with the remaining 34 questionnaires.

The questionnaire response rate was $15.6 \%$, less compared to similar studies. Reference should be made to the period of implementation of the survey, as well as to its subject. Greece is going through a period of financial crisis and many enterprises are facing serious economic problems. It is worth noting that firms that were among the most profitable in their sector in 2014, were found to suffer losses the next years. In addition, several companies did not respond to the questionnaire due to limited-time pressures of the quality manager, following staff reduction due to crisis. 
In order to measure IT implementation, 6 categories were used (Martinez-Lorente et al., 2004), based on the purpose of the use of each IT. Those are: Administrative IT, Communications-related IT, Decision support IT, Production planning IT, Product design IT and Production control IT. TQM implementation construct was formed by a total of seven items in the present study, as proposed by Martinez-Lorente et al. (2004). To measure the impact of IT on TQM dimensions, 8 constructs were used, regarding each one of the eight TQM dimensions: top management support, workforce management, employees attitude and behavior, customer relationship, supplier relationship, product design process, process flow management and quality data and reporting.

Moreover, operational performance and quality performance, used as indicators of the overall company performance, were measured by a 5 and 4 -scale item, respectively. Net profit margin and value added per employee, were calculated, based on the public balance sheets of the companies.

Data analysis was performed using IBM SPSS (v.24).

\section{FINDINGS}

In the cases to follow, concerning correlations between the adoption of IT and TQM with various parameters relating to quality, performance and competition as well as business characteristics, both the dimensions of the two basic concepts of the study (IT and TQM) and the other measurements are expressed in a continuous measurement scale, and therefore in all cases the Pearson criterion was used to detect the correlations between them. In all cases statistically significant were the correlations, in which the observed significance level (Sig. Or p-value) was less than 0.05 . For these correlations, Pearson index values may range from -1 to 1 with the sign (-), denoting relationships that the sizes were inversely proportional. In all cases, Pearson's absolute values rating up to 0.6 were characterized as weak, values at least 0.6 are considered moderately strong and values greater than 0.9 as very strong. To estimate the dimensions of concepts represented by more than one question, the dimensions of IT adoption were the average of the responses given to the corresponding five-tier scale.

The sample companies were mainly from the "other food sector" (41.2\%), while $20.6 \%$ were from the beverage industry and $17.6 \%$ from the dairy sector. The majority of questionnaires was answered by quality managers of the companies $(73.5 \%)$, while the remaining $26.5 \%$ was answered by the CEO of the company.

Based on the EU's report on the size of a firm (European Commission, 2015), companies were divided into four categories: micro ( $\leq 10$ employees), small (10-49 employees), medium (50-249 employees) and large enterprises ( $\geq 250$ employees). $58.8 \%$ of the companies that participated in this survey were medium-sized, while $35.3 \%$ were large and $5.9 \%$ were small. There was no company in the "micro" category, based on its employees. Regarding the years of operation of the enterprises, it was noticed that $25 \%$ of them were active in the industry for more than 40 years, and none of them were new entrants, in the sense that they operate less than 10 years. Table 1 shows the rates of business responses.

In addition, previous studies have investigated the type of production process (Martinez-Lorente et al., 2004), and no significant effect was found on TQM or IT implementation. In the present study, the number of production lines were recorded, in order to check whether this factor affects the adoption of IT or TQM. The majority of the companies (47.1\%) had less or equal to five production lines, while only $20.6 \%$ of them has more than 10 production lines.

To measure company performance, four indicators were used, being operational performance, quality performance, Net profit margin and value added per employee, indicated as an alternative measure to profitability on sales turnover (PTS) and profitability per employee (PE), used by Martinez-Lorente et al. (2004), where both (PTS and PE) were not significantly related to TQM and IT implementation. Value added per employee is operating profit added to salaries, wages and payroll expenses and then divided by the average number of employees. Net profit margin is typically expressed as a percentage, showing how much of each dollar/euro collected by a company as revenue translates into profit. To calculate net profit margin, net profit was divided by revenue. 
Table 1. Company characteristics

\begin{tabular}{|c|c|c|}
\hline Factor & Scale & $\%$ \\
\hline \multirow{4}{*}{$\begin{array}{l}\text { Size } \\
\text { (based on number of employees) }\end{array}$} & Micro: $<10$ & 0 \\
\hline & Small: 10-49 employees & 5.9 \\
\hline & Medium: 50-249 employees & 58.8 \\
\hline & Large: $\geq 250$ employees & 35.3 \\
\hline \multirow{3}{*}{$\begin{array}{l}\text { Size } \\
\text { (based on sales turnover) }\end{array}$} & Small: 2-10 million euros & 8.8 \\
\hline & Medium: 10-50 million euros & 50.0 \\
\hline & Large: $>50$ million euros & 41.2 \\
\hline \multirow[t]{5}{*}{ Sector } & Vegetable \& animal oils \& fats & 8.8 \\
\hline & Dairy products & 17.6 \\
\hline & Drinks & 20.6 \\
\hline & Meat / meat products & 11.8 \\
\hline & Other food items & 41.2 \\
\hline \multirow[t]{5}{*}{ Years of operation } & $1-10$ & 0 \\
\hline & $11-20$ & 5.9 \\
\hline & $21-30$ & 8.8 \\
\hline & $31-40$ & 11.8 \\
\hline & $>40$ & 73.5 \\
\hline \multirow[t]{3}{*}{ Production lines } & $1-5$ & 47.1 \\
\hline & $6-10$ & 32.4 \\
\hline & $>10$ & 20.6 \\
\hline
\end{tabular}

\subsection{Company Characteristics and Implementation of IT and TQM}

As mentioned above, the size of a company, regarding business characteristics, was measured in terms of number of employees and sales turnover. The results, as shown in Table 2 and 3, showed that sales turnover and number of employees of the company are positively and significantly related to TQM implementation (Table 2), while they were also positively and significantly related to the majority of IT implementation scales, except for IT construct for production planning (Table 3). Moreover, it seemed that administrative IT construct was not related to sales turnover, though related to the number of employees. (For all the cases to follow, correlation significant at the 0.01 level (2-tailed), is marked **, and correlation significant at the 0.05 level (2-tailed) is marked *).

Regarding the number of production lines of each company, the results confirmed a positive and significant relation to TQM implementation and three out of six IT constructs, that being Decision Support IT, Production planning IT and Production Control IT (Table 4).

Moreover, the sector that a company operates and the number of years of active operations in the industry did not appear to affect either the IT implementation, nor the TQM implementation.

\subsection{Company Performance}

Company performance was described by a number of variables, being net profit margin, value added per employee, quality performance and operational performance. As regards company's quality performance, it appeared to affect the implementation of IT and TQM, as $\mathrm{p}<0.05$ for all the IT and TQM implementation constructs. In addition, Operational performance appeared to be positively 
Table 2. Correlation between TQM implementation and size of the company (in terms of sales turnover and number of employees)

\begin{tabular}{|l|l|l|}
\hline & \multicolumn{1}{|c|}{ Sales turnover } & \multicolumn{1}{c|}{ Number of employees } \\
\hline TQM Implementation & $.371^{*}$ & $.513^{* *}$ \\
\hline
\end{tabular}

Table 3. Correlation between IT implementation and size of the company (in terms of sales turnover and number of employees)

\begin{tabular}{|l|l|l|l|l|l|l|}
\hline & ADMINIT & COMMIT & \multicolumn{1}{|c|}{ DECIT } & PLANIT & DESIGNIT & CONTROLIT \\
\hline Sales turnover & .199 & $.558^{* *}$ & $.534^{* *}$ & .174 & $.460^{* *}$ & $.484^{* *}$ \\
\hline $\begin{array}{l}\text { Number of } \\
\text { employees }\end{array}$ & $.372^{*}$ & .322 & $.505^{* *}$ & .237 & $.382^{*}$ & $.436^{* *}$ \\
\hline
\end{tabular}

Table 4. Correlation between TQM and IT implementation constructs and number of production lines

\begin{tabular}{|l|l|l|l|l|l|l|l|}
\hline & ADMINIT & COMMIT & DECIT & PLANIT & DESIGNIT & CONTROLIT & $\begin{array}{c}\text { TQM } \\
\text { Implementation }\end{array}$ \\
\hline Production lines & .241 & .187 & $.460 *$ & $.342 *$ & .313 & $.494 * *$ & $.490 * *$ \\
\hline
\end{tabular}

related to TQM implementation, and to limited IT constructs, that being Administrative IT construct and production planning IT construct, though correlation is not strong enough. Additionally, net profit margin and value added per employee were found insignificant regarding the IT and TQM implementation (see Table 5).

\subsection{IT and IT Impact on TQM}

Based on Martinez-Lorente et al. (2004), if IT has an impact on TQM, then it is reasonable to suppose that when IT is employed intensively, the impact on TQM will be greater. Correlation appeared moderate for the majority of the factors, while only correlation between employees' attitude and production design support, was not significant at the level 0.05 (Table 6).

\section{DISCUSSION}

The present study is an attempt to implement the suggested IT and TQM analysis model in food and drink companies in Greece. In order to test the relationships, an updated form of the instrument suggested by Martinez-Lorente et al. (2004) was used, bringing up-to-date IT to the question. All scales were tested to be reliable according to Cronbach's alpha criteria.

Company size (based on terms of sales turnover and number of employees), affects the TQM implementation, and the majority of IT implementation constructs. Though, in particular administrative IT construct is not related to sales turnover, nevertheless related to the number of employees. This means that investments in administrative IT are made irrespective of turnover, as the information processed by an enterprise on a daily basis is not inherent in its economic efficiency. On the other hand, the influence of IT implementation on the number of employees may indicate that the volume of information to be handled, as well as the number of people who deal with it, is interdependent.

The number of production lines of companies was also tested, leading to a positive relation among certain IT constructs and TQM implementation. As a result, it may be assumed that the perception of benefits of TQM and IT, are related to the number of production lines, and the number of end-products manufactured by the companies, based on the fact that IT constructs related to them, were the ones dealing with production planning, production control and decision support systems. 
Table 5. Correlation between TQM and IT implementation constructs and companies' performance

\begin{tabular}{|l|l|l|l|l|l|l|l|}
\hline & ADMINIT & COMMIT & DECIT & PLANIT & DESIGNIT & CONTROLIT & $\begin{array}{c}\text { TQM } \\
\text { Implementation }\end{array}$ \\
\hline Net profit margin & -.202 & -.313 & -.160 & -.033 & -.334 & -.320 & -.088 \\
\hline Value added per employee & .106 & .332 & .225 & .145 & .172 & .023 & .151 \\
\hline Quality Performance & $.689^{* *}$ & $.463^{* *}$ & $.607^{* *}$ & $.506^{* *}$ & $.482^{* *}$ & $.464^{* *}$ & $.661^{* *}$ \\
\hline Operational Performance & $.350^{*}$ & .060 & .270 & $.406^{*}$ & .199 & .265 & $.556^{* *}$ \\
\hline
\end{tabular}

Table 6. Correlation between TQM and IT implementation constructs and number of production (Pearson Correlation)

\begin{tabular}{|c|c|c|c|c|c|c|}
\hline & $\begin{array}{l}\text { ADMIN } \\
\text { IT }\end{array}$ & $\begin{array}{l}\text { COMM } \\
\text { IT }\end{array}$ & $\begin{array}{c}\text { DEC } \\
\text { IT }\end{array}$ & $\begin{array}{l}\text { PLAN } \\
\text { IT }\end{array}$ & $\begin{array}{c}\text { DESIGN } \\
\text { IT }\end{array}$ & $\begin{array}{c}\text { CONTROL } \\
\text { IT }\end{array}$ \\
\hline Top Management Support ITTQM & $.586^{* *}$ & $.501 * *$ & $.547 * *$ & $.563 * *$ & $.437 * *$ & $.718^{* *}$ \\
\hline Customer Relations ITTQM & $.667 * *$ & $.408 *$ & $.725 * *$ & $.582 * *$ & $.588 * *$ & $.666^{* *}$ \\
\hline Supplier Relations ITTQM & $.740^{* *}$ & $.541 * *$ & $.628 * *$ & $.657 * *$ & $.493 * *$ & $.687 * *$ \\
\hline Workforce Management ITTQM & $.649 * *$ & $.524 * *$ & $.656^{* *}$ & $.519 * *$ & $.490 * *$ & $.732 * *$ \\
\hline Employees Attitude ITTQM & $.364^{*}$ & $.365^{*}$ & $.342 *$ & $.500 * *$ & .144 & $.439 * *$ \\
\hline Production Design Process ITTQM & $.665 * *$ & $.659 * *$ & $.618^{* *}$ & $.588 * *$ & $.528 * *$ & $.795 * *$ \\
\hline Process Flow ITTQM & $.685 * *$ & $.536 * *$ & $.737 * *$ & $.525 * *$ & $.627 * *$ & $.691 * *$ \\
\hline Quality Info ITTQM & $.777 * *$ & $.706^{* *}$ & $.757 * *$ & $.645^{* *} *$ & $.624 * *$ & $.779 * *$ \\
\hline
\end{tabular}

Company performance was not significant in terms of net profit margin and value added per employee. No conclusive results are given about company performance as only quality performance appears to affect IT and TQM implementation. Regarding the relation between IT and TQM implementation and company's performance, the current financial situation in Greece, which is considered doubtful, should be taken into consideration.

Results show that there is a moderate relation between IT implementation and impact of IT on TQM. This indicates a connection, not so strong though, between the two implementations and that drivers affecting IT adoption may also lead to TQM adoption by the company. It's worth mentioning that IT industry is characterized by rapid growth, thus may also drift enhancement in the TQM field.

\section{LIMITATIONS AND RECOMMENDATIONS}

Certain restrictions arise: The results have been promulgated on the basis of opinions expressed by one individual of a firm due to the fact that per each organization only one questionnaire was mailed to the quality manager of the company. Many researchers find that the respondent's judgment may sometimes not reflect the true situation in regard to the representing business. Future research should focus on covering both aspects of IT manager and business administrator.

The size of the sample in each survey is crucial for further generalization of its effects. In the present study, attempting to collect questionnaires was not as successful as expected. This may be due to the structure of the questionnaire, the availability of quality managers at the given time, and the orientation of the survey to profitable companies with the highest turnover. In a subsequent survey, it is suggested to include in the sample, the total number of food and drink enterprises based in Greece, irrespective of turnover, as it is expected that quite interesting results will be retrieved from these companies. 
Finally, the rapid development in the IT industry, as well as the constant quest by companies for more efficient ways of managing their information and their entire processes, as well as human resources, make both TQM and IT research sectors, suitable for further development and analysis. 


\section{REFERENCES}

Abdi, R., Edalat, D., \& Shutbi, A. (2013). IT service improvement through the Total Quality Management. International Journal of Information and Computer Science, 2(7), 141-145.

Agus, A., Barker, S., \& Kandampully, J. (2007). An exploratory study of service quality in the Malaysian public service sector. International Journal of Quality \& Reliability Management, 24(2), 177-190. doi: $10.1108 / 02656710710722284$

Ahmed, N., \& Ravichandran, R. (1999). An information systems design framework for facilitating TQM implementation. Information Resources Management Journal, 12(4), 5-13. doi:10.4018/irmj.1999100101

Alqahtani, F., \& Alghrair, N., \& AbdAziz, A. (2017). TQMIS: The Relationship between Total Quality Management and Information Systems. International Advanced Research Journal in Science. Engineering and Technology, 4(5), 114-117.

Ang, C., Davies, M., \& Finlay, P. (2000). Measures to assess the impact of information technology on quality management. International Journal of Quality \& Reliability Management, 17(1), 42-66. doi:10.1108/02656710010300135

Bandyopadhaya, J. (2003). A Total Quality Management Information system for Auto Parts Manufacturers in the United States. International Journal of Management, 20(2), 187-192.

Bouranta, N., Psomas, E. L., \& Pantouvakis, A. (2017). Identifying the critical determinants of TQM and their impact on company performance Evidence from the hotel industry of Greece. The TQM Journal, 29(1), 147-166. doi:10.1108/TQM-11-2015-0142

Chandiwana, T., \& Pather, S. (2016). A Citizen Benefit Perspective of Municipal Enterprise Resource Planning Systems. The Electronic Journal Information Systems Evaluation, 19(2), 85-98.

Christensson, P. (2006). IT Definition. Retrieved 03 02, 2017, from https://techterms.com/definition/it

Crosby, P. (1979). Quality Is Free. New York: McGraw-Hill, Inc.

Davenport, T. H. (1998). Putting the enterprise into an enterprise system. Harvard Business Review, 121-131. PMID:10181586

Deming, W. (1986). Out of Crisis. Cambridge, MA: Massachusetts Institute of Technology, Center for Advanced Engineering Study.

Demirbag, M., Tatoglu, E., Tekinkus, M., \& Zaim, S. (2006). An analysis of the relationship between TQM implementation and organizational performance: Evidence from Turkish SMEs. Journal of Manufacturing Technology Management, 17(6), 829-847. doi:10.1108/17410380610678828

Dervitsiotis, K. N. (1999). Quality in Greece: Past and present. The TQM Magazine, 11(2), 84-87. doi: $10.1108 / 09544789910257000$

Dewhurst, F., Martınez-Lorente, A., \& Sanchez-Rodriguez, C. (2003). An initial assessment of the influence of IT on TQM:A multiple case study. International Journal of Operations \& Production Management, 23(4), 348-374. doi:10.1108/01443570310467302

Douglas, T. J., \& Judge, W. Q. Jr. (2001). Total Quality Management Implementation and Competitive Advantage: The Role of Structural Control and Exploration. Academy of Management Journal, 44(1), 158-169.

Eng, Q. E., \& Yusof, S. M. (2003). A survey of TQM practices in the Malaysian electrical and electronic Industry. Total Quality Management, 14(1), 63-77. doi:10.1080/14783360309708

English Oxford living Dictionaries. (2016, 11 12). English Oxford living Dictionaries. Retrieved from https:// en.oxforddictionaries.com

European Commission. (2015). User guide to the SME definition. Luxembourg: Publications Office of the European Union, 2015. Retrieved from http://ec.europa.eu/growth/smes/business-friendly-environment/smedefinition/ 
European Commission. (2017). Smart use of ICT for SMEs. Retrieved from https://ec.europa.eu/growth/industry/ policy/digital-transformation/smart-use-ict-smes_en

Feigenbaum, A. V. (1983). Total quality control (3rd ed.). New York: McGraw-Hill.

FEIR. (2017). Food and Drink Industry: Facts \& Figures 2016. Athens: Foundation for Economic \& Industrial Research - IOBE.

Fotopoulos, C. B., \& Psomas, E. L. (2009). The impact of "soft" and "hard" TQM elements on quality management results. International Journal of Quality \& Reliability Management, 26(2), 150-163. doi:10.1108/02656710910928798

Fuentes, M. M., Montes, J. F., \& Fernández, L. M. M. (2006). Total Quality Management, strategic orientation and organizational performance: The case of Spanish companies. Total Quality Management \& Business Excellence, 17(3), 303-323. doi:10.1080/14783360500451358

Gabriel, Y., Fineman, S., \& Sims, D. (2000). Organizing and organizations: an introduction (2nd ed.). London: Sage.

Garvin, D. (1984). What does product quality mean? Sloan Management Review, 25-43.

Garvin, D. (1988). Managing Quality - the strategic and competitive edge. New York: Free Press.

Ginige, S., \& Samarasinghe, S. (2008). Identifying the effect of information technology on total quality management for achieving quality performance. In International Conference on total quality management for achieving quality performance.

Gotzamani, K., Theodorakioglou, Y., \& Tsiotras, G. D. (2006). A longitudinal study of the ISO 9000 (1994) series' contribution towards TQM in Greek industry. The TQM Magazine, 18(1), 44-54. doi:10.1108/09544780610637686

Gunasekaran, N., Arunachalam, V., \& Arunachalam, S. (2006). TISIT: A model for integrating TQM with software and information technologies. The TQM Magazine, 18(2), 118-130. doi:10.1108/09544780610647847

Issac, G., Rajendran, C., \& Anantharaman, R. (2004). A holistic framework for TQM in the software industry: A confirmatory factor analysis approach. The Quality Management Journal, 11(3), 35-47. doi:10.1080/10686 967.2004.11919120

Juran, J., \& Gryna, F. (1993). Quality planning and analysis. McGraw-Hill Inc.

Juran, J. M. (1988). Juran's Quality Control Handbook (4th ed.). New York: McGraw-Hill.

Kampouridis, G., Yiannopoulos, A., Giannopoulos, G., \& Tsirkas, S. (2015). The relationship between TQM and financial performance of Greek companies of structural construction sector during crisis period. Journal of Economics and Business, 18(1).

Keramati, A., \& Albadvi, A. (2009). Exploring the relationship between use of information technology in total quality management and SMEs performance using canonical correlation analysis: A survey on Swedish car part supplier sector. International Journal of Information Technology and Management, 8(4), 442-462. doi:10.1504/ IJITM.2009.024805

Khanam, S., Talib, F., \& Siddiqui, J. (2014). A Review of TQM and IT Research in the ICT Industry: An Agenda for Future. International Journal of Information and Computer Science, 3(0), 64-84. doi:10.14355/ ijics.2014.03.009

Korfiatis, C. (2017). Greek Industry. Retrieved from http://inr.gr/?p=a2104

Lee, C. (2005). Information Technology for the Food Manufacturing Industry: Big Future, Slow Start. Journal of International Food \& Agribusiness Marketing, 17(2), 165-193. doi:10.1300/J047v17n02_09

Martinez-Lorente, A. R., Sanchez-Rodriguez, C., \& Dewhurst, F. W. (2004). The effect of information technologies on TQM: An initial analysis. International Journal of Production Economics, 89(1), 77-93. doi:10.1016/j.ijpe.2003.06.001

Matta, K., Chen, H., \& Tama, J. (1998). The information requirements of total quality management. Total Quality Management, 9(6), 445-461. doi:10.1080/0954412988389 
McFarlan, F. (1984). Information technology changes the way you compete. Harvard Business Review, 63(3), 98-103.

Parasuraman, A., Zeithaml, V., \& Berry, L. (1985). A conceptual model of service quality and its implication. Journal of Marketing, 49(4), 41-50. doi:10.1177/002224298504900403

Parzinger, M., \& Nath, R. (2000). A study of the relationships between total quality management implementation factors and software quality. Total Quality Management, 11(3), 353-371. doi:10.1080/0954412006874

Perez-Arostegui, M., Benitez-Amado, J., \& Tamayo-Torres, J. (2012). Information technology-enabled quality performance: An exploratory study. Industrial Management \& Data Systems, 112(3), 1-25. doi:10.1108/02635571211210095

Perez-Arostogui, M. N., Bustinza-Sanchez, F., \& Barrales-Molina, V. (2015). Exploring the relationship between information technology competence and quality management. BRQ Business Research Quarterly, 18(1), 4-17. doi:10.1016/j.brq.2013.11.003

Peters, T., \& Waterman, R. (1982). In search of excellence: lessons from America's best-run companies. New York: Harper \& Row.

Porter, M., \& Millar, V. (1985). How information gives you competitive advantage. Harvard Business Review, 63(4), 149-160.

Prajogo, D. I., \& McDermott, C. M. (2005). The relationship between total quality management practices and organizational culture. International Journal of Operations \& Production Management, 25(11), 1101-1122. doi:10.1108/01443570510626916

Psychogios, A. G., \& Wilkinson, A. (2007). Exploring TQM awareness in the Greek national business context: Between conservatism and reformism cultural determinants of TQM. International Journal of Human Resource Management, 18(6), 1042-1062. doi:10.1080/09585190701321666

Reed, R., Lemak, D., \& Mero, N. (2000). Total quality management and sustainable competitive advantage. Journal of Quality Management, 5(1), 5-26. doi:10.1016/S1084-8568(00)00010-9

Sajjad, F., \& Amjad, S. (2012). Role of benchmarking in Total Quality Management: A case of Telecom Services Sector of Pakistan. Business Management Dynamics, 1(8), 34-44.

Sanchez-Rodriguez, C., \& Martinez-Lorente, R. (2011). Effect of IT and quality management on performances. Industrial Management \& Data Systems, 111(6), 830-840. doi:10.1108/02635571111144937

Siam, A., Khateeb, K., \& Waqqad, S. (2012). The role of Information system in implementing Total Quality Management. American Journal of Applied Sciences, 9(5), 666-672. doi:10.3844/ajassp.2012.666.672

Siddiqui, J., \& Rahman, Z. (2007). TQM principles' application on information systems for empirical goals: A study of Indian organizations. The TQM Magazine, 19(1), 76-87. doi:10.1108/09544780710720853

Sila, I. (2007). Examining the effects of contextual factors on TQM and performance through the lens of organizational theories: An empirical study. Journal of Operations Management, 25(1), 83-109. doi:10.1016/j. jom.2006.02.003

Talib, F., Rahman, Z., \& Qureshi, M. (2013). An instrument for measuring the key practices of total quality management in ICT industry: An empirical study in India. Service Business, 7(2), 275-306. doi:10.1007/ s11628-012-0161-y

Tiwari, G., \& Chaudhri, P. (2012). A study of the effect of information technology on TQM. World Journal of Science and Technology, 2(5), 21-23.

Tsakanikas, A., Danchev, S., Giotopoulos, I., Korra, E., \& Pavlou, G. (2014). ICT Adoption and Digital Growth in Greece. Athens, GR: Foundation for Economic and Industrial Research (IOBE).

Tsiotras, G., \& Gotzamani, K. (1996). ISO 9000 as an entry key to TQM: The case of Greek industry. International Journal of Quality \& Reliability Management, 13(4), 64-76. doi:10.1108/02656719610114407 
Vranaki, M., Vranakis, S., \& Sarigiannidis, L. (2015). Total Quality Management implementation in Greek businesses: Comparative assessment 2009-2013. International Journal of Production Management and Engineering, 3(2), 87-95. doi:10.4995/ijpme.2015.3245

Sofia Zioupou is a PhD candidate in Agricultural Economics at the Department of Agricultural Economics of Aristotle University of Thessaloniki, Greece. She received her BSc in Agricultural Economics from the School of Agriculture, and MSc in Agricultural Economics both from Aristotle University of Thessaloniki. She works and has interests in agricultural economics, farm management and information technology in agriculture. She has conducted research in national and European funded projects. She has published in international conference proceedings and journals.

Basil Manos is a Professor of the Department of Agricultural Economics at the Aristotle University of Thessaloniki (AUTH), Greece. His research interests are in farm management and regional planning, environmental management, impact assessment, sustainability and efficiency. He has studied mathematics, economics, operational research and agricultural economics in AUTH and London School of Economics. He has conducted research in many national and European funded projects. His recent publications include papers in Regional Studies, Journal of Policy Modelling, British Food Journal, Journal of Environmental Planning and Management, Land Use Policy, Environmental Monitoring and Assessment, Environmental Impact Assessment Review, Proceedings of National Academy of Sciences, and Journal of Environmental Management.

Zacharoula S. Andreopoulou Associate Professor, Director in Lab. of Forest Informatics, Sector of Planning and Development of Natural Resources, Dept of Forestry \& Natural Environment, Aristotle University of Thessaloniki (AUTh), Greece. Her scientific interests include Forest \& Environmental Informatics, Internet \& Information Communication Technologies for environmental protection, green \& regional development, green technologies, green informatics and energy sustainability. Studies: B.Sc in Mathematics (AUTh), B.Sc in Forestry \& Natural Environment (AUTh), Ph.D. in Forest informatics (AUTh). Post-doc research (2004) at University of East London, UK, \& (2013) at University of Napoli "Parthenope", Italy. She has published 5 books in English and Italian, more than 65 papers in scientific journals, 200 papers in Int. Conferences proceedings, 17 book chapters, etc. Recognitionpositions: Chair in the Hellenic Association ICT in Agriculture, Food \& Environment Branch of North and Central Greece. Invited Speaker in environmental informatics and sustainability issues.

Irini Tzimitra - Kalogianni is a Professor of the Department of Agricultural Economics at the Aristotle University of Thessaloniki (AUTH), Greece. Her research interests include consumer behavior, advertising, sales promotion, marketing channels, food marketing, consumer attitude. She has studied Agricultural Economics in AUTH and obtained her PhD from the Department of Agricultural Economics and Food Marketing, Faculty of Agriculture and Biological Sciences of the Newcastle Upon Tyne University, England. She has published in international conference proceedings and journals. 